\title{
THE ANALYSIS OF SELECTED RESOURCE MANAGEMENT TOOLS USED IN THE CZECH REPUBLIC
}

\author{
H. JÁČOVÁ \& J. HORÁK \\ Faculty of Economics, Technical University of Liberec, Czech Republic.
}

\begin{abstract}
This submitted paper deals with the selected tools that are a part of resource management in the context of sustainable development. These instruments mainly cover corporate social responsibility, enterprise resource planning systems and strategic management with selected management models. Enterprise resource planning systems are the information base and support tools that a company's management uses for making decisions. The aim of these tools is to support a decrease in the consumption of raw materials, energy and other limited resources, which in turn increases the company's performance. This is mainly due to lower costs and increased corporate profitability. On the other hand, all these activities help to reduce the unfavorable ecologic impacts of business activities.

This paper discusses the various ways to increase business performance through selected strategic management models through improving a company's competitiveness. The last part of the article is aimed at looking at the results of a survey that was conducted in the Czech Republic at the beginning of 2013. The research was focused on companies located in this country and it answered questions that surrounded on how these companies improved and increased their business performance in the market from the sustainable development point of view.

Keywords: corporate social responsibility, enterprise, enterprise resource planning systems, information systems management by objectives, models of strategic management, resource management, strategic management, sustainable development, survey, total quality management.
\end{abstract}

\section{INTRODUCTION}

In today's global world where markets are more connected than ever before, information about the financial position and performance of companies is becoming more and more important. Enterprises have been continuously striving to boost their performance in order to be able to succeed in this highly competitive market. Though in many cases, the negative social and environmental impacts on all of civilization are somehow overlooked. The success of advanced economies was mainly based on the acquisition and exploitation of new colonies, natural resources and outlets. Many of the enterprises unfortunately developed to the detriment of other natural, social and economic factors, and this situation has subsequently affected multiple generations. However, this way of thinking has recently changed considerably and - in connection with sustainable development principles - many enterprises have started to apply a completely different approach with regard to their hunt for improved performance. They obviously realize their responsibility towards the environment and population and this trend will surely continue to expand even further. The environmental consequences of companies' and human actions are obviously more visible and that puts pressure on them to ease their impact [1].

The CSR concept was first dealt with by foreign theorists who are specialized in management in the second half of the 20th century. The crucial point is considered to have occurred in 1953, when American economist Howard Bowen published his book entitled Social Responsibilities of the Businessman in which he defined CSR and stated that it was the social responsibility of enterprises in modern times [2].

The concept of company value management is becoming a new paradigm. From the accounting perspective, a company is successful if it generates profit. This view is, however, in terms of the 
theory of value management, insufficient. It is necessary to achieve such a level of profit that the return on equity exceeds the alternative costs of equity.

The social responsibility concept is today becoming a more and more important part of corporate activities, though it is still a voluntary concept. The reason is that no company is an isolated entity, but rather part of society's political, economic and social environment. Responsible behavior towards both stakeholders and the environment should become an integral part of any corporate strategy. The activities and behavior of corporations do not remain unknown to their surroundings - more and more often, the media is reporting on various corporate scandals despite the fact that the general public expects more friendly behavior by companies towards the environment in which they work, not just acting to increase their own success.

To secure their competitiveness and future development, companies have to adapt to their external environment. The faster the reaction is, the better results they achieve. Therefore, having a flexible strategy and measuring performance is becoming more important for securing a company's future existence. This can be achieved with the help of financial management that helps to set up strategic goals, strategy and ways of measuring performance. These goals should be both quantitative and qualitative. Classical performance measurement is not sufficient because it is based on historical data. To enable a company to effectively manage their finances, business information systems are continuously improved. These information systems provide a company's management with all the information required to be able to make correct decisions and successfully manage the company. For this purpose, new or modified enterprise resource planning (ERP) systems are used. These systems allow for faster reactions to the current situation within a company as well as to the changes in its environment. The term new management system will be understood in the following text as systems including, but not limited to Balanced Scorecard, Management by Objectives and Total Quality Management. These systems have been used abroad for many years. In the Czech Republic, they have been used more and more frequently [3].

\section{METHODOLOGY}

The methodology in this paper is based on a literature overview that not only covers scientific publications but also some scientific articles that have been published on the subject matter. For the purpose, an electronic questionnaire was taken in January and February 2013 in companies situated in the Czech Republic. The vast majority of analyzed companies were located in the Central and Northeastern parts of Bohemia. First, a pilot questionnaire was issued, through which it was verified that the respondents understood the given questions. The final version of the questionnaire was based on their answers and comments.

The questionnaires were answered by company managers - mainly financial managers. The companies were focused on automotive production and the production of glass components and furniture. The above-mentioned industries are typical in this area. The research team received 104 completed questionnaires. According to data from the Czech Statistical Office, there are approximately 10,000 business entities in the Liberec Region. Based on this figure, a relevant $1 \%$ sample was selected since, unfortunately, companies in the Czech Republic are not interested in responding to assigned questionnaires and thus participating in research.

The survey consisted of three main parts: the first part contained basic information about the business entities, the second part was focused on the usage of ERP systems in these companies and the last part analyzed their financial management. The main goal of the survey was to monitor the present situation with regard to the practical use of performance measurement systems, mainly with a focus on strategic management innovated approaches. The survey was prepared in an electronic format and it contained 50 questions. To obtain relevant information about the analyzed companies, 
both closed and open questions were asked. The task of the respondents was to answer open questions with no options available. These answers were selected by companies at their sole discretion. Closed questions included some options from which the respondents could choose. Within the scope of the survey, 120 companies were contacted and we received back 104 completed questionnaires. Ninety-six of them were usable. There was a certain risk that the respondents may understand the questions incorrectly, and this could affect the results of the survey.

The data collected by the questionnaires were thoroughly analyzed. These data were processed with the help of an Excel spreadsheet. The results of each of the questions were published as a percentage share of the respective responses of all companies analyzed. In this paper, only few selected topics are mentioned.

\section{SELECTED DEFINITIONS OF SUSTAINABLE DEVELOPMENT}

In recent years, the question of the existence of a symbiotic relationship between economic growth and environmental protection has become quite topical. That is why discussions about sustainable development occur so frequently nowadays. Sustainable development is defined and characterized in various ways. The concept of sustainable development is based on the idea of achieving a dynamic balance in various areas. From the practical point of view, it is the balance between production and consumption, the balance between the economy and the environment, and the balance between development and protection. In spite of the differences and open question, most people agree that sustainable development involves significant changes in the economy in order to improve environmental quality and human welfare in a long-term perspective [4].

Waas, Verbruggen and Wright stated that, 'contemporary society considers sustainable development to be the best way to address these complex and interrelated problems for the sake of current and future generations and for the integrity of the planet' [5].

The most widely known and also the simplest definition of sustainable development was presented by Gro Harlem Brundtland in 1987: 'Sustainable development is development that meets the needs of the present without compromising the ability of future generations to meet their own needs' [6]. In other words, as often quoted: 'We did not inherit this planet from our ancestors, but rather borrowed it from our children'. This definition was mentioned in the report entitled 'Our Common Future' published by the UN World Commission on Environment and Development (UN WCED). The basic principles surrounding the sustainable use of natural resources were formulated by Daly and Cobb [7]. According to the cited authors, the permanent sustainability principles may be summarized as follows:

- The level of use of non-renewable resources may not exceed the level of development/growth of replacement renewable resources.

- The level of use of renewable resources may not exceed their rate of regeneration.

- The level of emissions of pollutants into the environment shall not exceed the environment's ability to assimilate them.

The question of sustainable use of renewable resources is quite obvious and understandable, though in practice it is often ignored. The assimilation ability of the environment and the related permissible emission levels are often the subject of frequent discussion. Not only should value be admitted to the environment, nature and landscape, but also should the price; both negative and positive externalities must be internalized so the market may become a truly functioning market with respect to natural values. 
In the Czech Republic, sustainable development is defined by Act No. 17/1992 Coll., on the Environment (Section 6) as follows: 'Sustainable development is development that maintains for both the present and future generations the possibility to meet their basic life necessities without compromising the diversity of nature and while preserving the natural functions of ecosystems'. Problems of sustainable development in the Czech Republic are being solved with the help of Structural Funds of the European Union. The main goal of these funds is to help the development of economic and social area and thereby to contribute to the improvement of the environment.

The question of sustainable development was dealt with by Josef Vavroušek, the first Czechoslovak Minister of the Environment, who defined it as follows: '... sustainable life - or more precisely the way of living - is aimed at looking for the harmony between humans and nature, between society and its environment so that we meet the ideals of humanism and respect life and nature in all forms and at all times...' [8].

Rynda defined sustainable development as '... a complex set of strategies allowing people - by means of economic resources and technologies - to satisfy human needs, including material, cultural and spiritual, while fully respecting environmental limits. To make this possible within the global scope of the current world, we must redefine these strategies into local, regional and global' [9].

The aim of sustainable development is to provide society with perspective visions. The activities that meet current needs may be of a short-term nature. Sustainable development is a complex concept that covers all human activities down to the local levels. The aim of sustainable development is to improve the quality of life for both the present and future generations, while protecting Earth's resources. Sustainable development is based on democracy, where the government respects the basic rights of freedom, equal opportunities and cultural diversity. It further supports high levels of employment in the economy, with an emphasis on education, innovation, social and territorial cohesion and the protection of human life and the environment.

\subsection{The basic pillars of sustainable development}

The concept of sustainable development is an alternative model for the development of society compared with the dominating industrial economy. In general, sustainable development may be understood as the achievement of balance between economic sustainability, social sustainability and environmental sustainability. Considering the levels of policy and society, we can conclude that sustainable development needs a balanced growth in all four relatively independent areas: environmental, economic, social and political.

Sustainable development is often understood only as environmental protection. The fact is that environmental protection is only one-third of it. In addition to the environmental pillar, there are also economic and social pillars. Therefore, we can consider sustainable development to be the effort to reach a balance between economic, social and environmental areas. The implementation of basic sustainable development principles over the long run is only possible if all of society is involved. Impulses for improvement must come not only from the public but also from the private sector and non-governmental non-profit organizations. However, civil responsibility plays a rather important and key role in this process as well. We may conclude that environmental protection is the limiting factor of sustainable development, while the economy is its tool. The aim of sustainable development is to ensure a quality life for everyone. Sustainable development is often understood as a principle comprising three pillars - environmental sustainability, economic sustainability and social sustainability [10]. 
3.1.1 The environmental pillar

The environmental pillar mainly represents the protection of fauna, flora, air, water, soil, ecosystems and natural resources. The key factor is the use of mineral resources, non-renewable energy sources, raw materials and also space and waste. To avoid deterioration and to boost improvement of the environment, we must focus on priorities, such as setting limitations on global warming, inhibiting biodiversity loss, controlling and reducing harmful emissions and their entering the natural water and nutrient cycle [11].

\subsubsection{The economic pillar}

The economic pillar represents economic development and improving economic competitiveness. Economics is a rather strong and efficient tool of sustainable development that may, for instance, help to ensure the profitability of sustainable investments both in the public and private sectors, to transfer the results of research aimed at sustainable development issues into manufacturing and everyday life and to influence the decision-making process by consumers on all levels. The economic pillar covers both incentive tools for those economic subjects that do not want to adapt themselves to the imperative of sustainability voluntarily, as well as parameters - fully market compatible mechanisms - that suddenly allow for a completely functioning market with all its benefits to protect the environment, not to put it in danger or to impair it. This pillar influences a company's capital structure [12].

\subsubsection{The social pillar}

The social pillar of sustainable development represents the true meaning of what it is to be a human being, social appreciation and the development of culture and maintenance of traditions. With regard to this pillar, the most important aspect is the correct functioning of the family, municipalities, public institutions and overall society. The horizontal theme of equal opportunities is also an integral part of corporate social responsibility (CSR).

As these three pillars of sustainable development mutually interact, a system that does not give preference to any one of them must be established. For example, in the field of environmental protection, excessive support of environmental features and issues may lead in economic stagnation in the area. On the other hand, if economic development issues are preferred, the environmental situation may get worse. Also, excessive stress put on social aspects may result in considerable problems - for example, decreased competitiveness in economic competition between the regions.

Some authors further divide the social pillar into political and social pillars. That is why we sometimes talk about four basic pillars of sustainable development that are relatively independent:

- environmental

- economic

- social and

- political.

The environmental dimension means adopting active measures aimed at preventing existing and unsustainable harm to the environment and automatically including them in any strategy that aims to become sustainable. This does not only apply to governments of individual countries and international communities, because these strategies must involve consumers who may become an important partner for enforcing changes. The manufacturing sector will then have sufficient motivation to implement changes resulting in continuous sustainability. This is, however, not a problem only for manufacturers and technology. In connection with consumption, some environmentally oriented thinkers talk about 
the concept of 'voluntary modesty', which means at a certain point, one should realize that from a certain level of richness, the quality of life no longer improves (i.e. with a third or more car, your feeling of happiness will not continue to grow - instead you might experience some frustration). In connection with this, we talk about global problems of the environment, such as climate changes, desertification, emissions, global warming, the greenhouse effect, pollution and smog [13].

\section{THE DEVELOPMENT AND SELECTED CHARACTERISTICS OF CORPORATE SOCIAL RESPONSIBILITY}

At the moment, there is no uniform global definition of CSR. There are only various definitions by authors from the academic sphere, non-government organizations and companies. CSR has its historical roots back in the 19th century, when Andrew Carnige published his opinion that rich people should have a moral duty to share their property with others [14]. Then, in the second half of the 20th century, the concept of CSR conception was explored by foreign management theorists. The breakthrough came in 1953 when US economist Howard Bowen released his book entitled Social Responsibilities of the Businessman. It contained a definition CSR and the idea that it should be the social responsibility of modern age corporations [15]. The boom in CSR appreciation came about in the 1960s, especially in the USA, where customers started to place emphasis on how companies presented themselves and what values they respected.

Another important milestone in the development of CSR was the statements made by CSR opponents, including Friedman and Levitt, who argued that corporations should be only responsible for generating profits and the only responsibility they have should be towards their shareholders. This opinion by Friedman and Levitt was rejected by Freemen, who claimed that companies are not responsible towards their shareholders, but rather towards their stakeholders who are affected by corporate activities and who also may influence such activities [16, 17]. Freemen also defined the term 'stakeholders' and helped managers who wanted to implement CSR into practice to find the right direction. The definition of stakeholders helped to determine the entities managers should be responsible towards.

Other authors, Aras and Crowther, stated that the concept of CSR should not be aimed only at the current impact, but especially at the future [18]. Other authors dealt with CSR in their papers, such as Mohr and Webb, who emphasized that it would be beneficial if socially responsible corporations would be managed per the stakeholder theory [19]. The modern concept of CSR was developed in the 1950s, formalized in the 1960s and spread in the 1970s, mainly in the USA. In Europe CSR, arrived in the 1990s. The basic document for enforcing CSR in EU countries is the Lisbon Conference of 2000, where the commitment to support CSR in all EU countries was assumed. The European Union characterizes CSR as follows: 'CSR is a voluntary integration of social and environmental viewpoints into everyday corporate operations and integration with the neighborhood'. CSR is the activities of managers that are aimed at improving the working conditions of their employees or supplier-customer relationships. Companies also focus their activities on environmental protection, closer cooperation with local administration and other concerned groups.

The European Commission prepared a new CSR definition in 2011. It concentrated on corporate competitiveness with a focus on risk management, cost savings, access to capital, customer relationships, human resource management and innovation capacity. The definition reacted to the developing and newly arising conditions in the area of CSR [20].

Currently, no standard generally applicable definition comprehensively characterizing the term CSR exists. This results from the fact that CSR is based on optionality, so firmly determined boundaries do not exist, which gives rise to space in which to construe and interpret the concept broadly and opens up space for holding a broad discussion on both the theoretical and practical 
fields. Alexander Dahlsrud, the most prominent personality dealing with this issue, analysed 37 definitions of the term in his scientific article entitled 'How Corporate Social Responsibility is defined: an Analysis of 37 Definitions'. The individual definitions most frequently include the environmental area, social area, economic area, stakeholders' area and optionality area. Dahlsrud discovered that $80 \%$ of the CSR definitions contained four of the five above-mentioned areas, and $97 \%$ of them contained three of the five above-mentioned areas. Based on the analysis, he came to the conclusion that although a number of such definitions exist, the definitions were in accord with each other [21].

The development of the view on CSR has also been dealt with by the prominent theorist A.B. Carroll, who splits the contents of CSR definitions into two main schools of thought. The first school of thought concentrates on an enterprise and the maximization of its profit regardless of the impact on society. However, he is of the opinion that that school of thought is wrong, and the scope of obligations of individual enterprises towards society should be widened, which he characterizes as the other school of thought. An enterprise should engage in activities that are desirable from the viewpoint of societal values and targets [22].

\subsection{The development of corporate social responsibility in the Czech Republic}

The concept of CSR did not appear in the Czech Republic until the second half of the 1990s because it had a central planning system for the previous $40+$ years. If we look at the history of undertaking in the territory of the former Czechoslovakia, we should not forget the success of the famous shoe-maker Tomáš Bat'a. He tried to create favorable conditions for his employees, providing them with many employee benefits. When the health and social department was established back in 1924, his employees already enjoyed above-average wages. He also built residential houses of a higher standard and hostels for his employees. Also, he employed the blind or otherwise handicapped people and significantly contributed to the development of the town of Zlín [14].

Today, the Business Leader Forum, a national CSR partner, enforces CSR in the Czech Republic and improves its general awareness and implements other related activities. The Business Leaders Forum was established in 1992 by leading Czech companies in cooperation with the international organization, The Prince of Wales International Business Leaders Forum. It is an association of international and Czech companies promoting the enforcement of ethics in business, the actual implementation of CSR concepts and cooperation amongst the corporate, public and non-profit sectors [14].

\subsection{The basic pillars of corporate social responsibility}

CSR is reflected in the integration of positive attitudes, actions or programmes into corporate strategies at top management levels. It calls for a shift from 'profit only' to a more complex and wider combination of people, planet and profit. In general, CSR is divided into three basic areas - economic, social and environmental. These three areas - pillars - cover all interests and activities that each socially responsible corporation should meet or adhere to. The three pillars should be as balanced as possible (Fig. 1).

4.2.1 The economic pillar

The fulfillment of economic pillar principles especially affects customers, suppliers, investors and the public sector. The economic pillar may be further divided into four basic themes. Each of them 


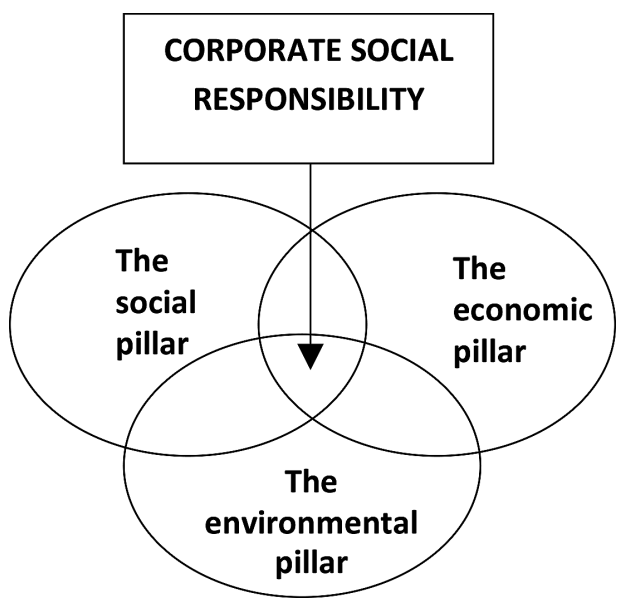

Figure 1: The pillars of corporate social responsibility. Source: self-produced.

covers specific activities. These basic themes and their breakdown into individual activities, including selected examples, can be found in Table 1 .

\subsubsection{The social pillar}

The social pillar should be divided into two areas - internal and external. The internal area is a company's social policy. The external area is especially aimed at philanthropy, altruism and cooperation with local communities, i.e. local interest groups. The social policy of each company and all its tools must be directed towards establishing a partnership with their employees. Employees must be offered the opportunity to make use of his/her active skills and abilities and through his/her satisfaction, the company achieves its goals. Social policy is a tool for making employees satisfied, resulting in increased company profits. The social pillar may be divided into seven basic themes. These basic themes and their breakdown into individual activities, including selected examples, can be found in Table 2.

\subsubsection{The environmental pillar}

The last pillar of activities that socially responsible corporations are focused on is the environmental pillar. An integral part of each entity must be its adherence to the principles of sustainable development ensuring a quality life for future generations. A company's responsible behavior towards the environment is expected by the general public. Moreover, companies themselves consist of people who should be concerned in reducing/eliminating negative impacts on the environment and sparing using natural resources, not only in favor of future companies, but also for future generations in general. Within this pillar, a company is especially aimed at reducing the negative impacts of its activities on the environment. In business practice, this environmental approach is implemented through environmental management. The main goals of this system are environmental protection, the protection of natural resources, reducing emissions, reducing pollutants, and the protection of the health and safety of employees and the public. The environmental pillar may be divided into six basic themes. These basic themes and their breakdown into individual activities, including selected examples, can be found in Table 3 . 
Table 1: The economic pillar of CSR.

\begin{tabular}{|c|c|c|}
\hline CSR themes & CSR activities & Examples of CSR activities \\
\hline \multirow{2}{*}{$\begin{array}{l}\text { Company } \\
\text { administration } \\
\text { and management }\end{array}$} & Transparency & $\begin{array}{l}\text { Publishing financial and non-financial } \\
\text { information }\end{array}$ \\
\hline & Behavior principles & $\begin{array}{l}\text { Business ethics principles and their } \\
\text { implementation in practice }\end{array}$ \\
\hline \multirow[t]{3}{*}{$\begin{array}{l}\text { Responsible } \\
\text { attitude towards } \\
\text { customers }\end{array}$} & $\begin{array}{l}\text { Feedback from } \\
\text { customers }\end{array}$ & $\begin{array}{l}\text { Customer satisfaction survey. A personal } \\
\text { approach towards customers. Efficiently resolv- } \\
\text { ing complaints }\end{array}$ \\
\hline & Customer service & $\begin{array}{l}\text { Loyalty programs. After-sales service. Barrier- } \\
\text { free access to stores. Accessibility of websites }\end{array}$ \\
\hline & $\begin{array}{l}\text { The quality and safety } \\
\text { of products and } \\
\text { services }\end{array}$ & $\begin{array}{l}\text { The provision of premium and safe products } \\
\text { to customers, while using quality certification } \\
\text { systems and quality standards }\end{array}$ \\
\hline \multirow{2}{*}{$\begin{array}{l}\text { Relationships with } \\
\text { suppliers and } \\
\text { other business } \\
\text { partners }\end{array}$} & Selection of suppliers & CSR introduction into supplier sourcing processes \\
\hline & $\begin{array}{l}\text { Solid business } \\
\text { relationships }\end{array}$ & $\begin{array}{l}\text { Early payment for products/services. Reliability. } \\
\text { Protection of data and information }\end{array}$ \\
\hline $\begin{array}{l}\text { Marketing and } \\
\text { advertisement }\end{array}$ & $\begin{array}{l}\text { Marketing and } \\
\text { advertising ethics }\end{array}$ & $\begin{array}{l}\text { The provision of clear and accurate information } \\
\text { about products and services. Adherence to ethics } \\
\text { principles when advertising (as released by the } \\
\text { Advertising Board) }\end{array}$ \\
\hline
\end{tabular}

Source: self-produced in accordance with [14].

Table 2: The social pillar of CSR.

\begin{tabular}{|c|c|c|}
\hline CSR themes & CSR activities & Examples of CSR activities \\
\hline \multicolumn{3}{|c|}{ Internal social policy tools } \\
\hline \multirow{2}{*}{$\begin{array}{l}\text { The involvement } \\
\text { of employees } \\
\text { and communi- } \\
\text { cation }\end{array}$} & Feedback & $\begin{array}{l}\text { Employee satisfaction surveys, keeping records about } \\
\text { employee complaints }\end{array}$ \\
\hline & $\begin{array}{l}\text { Internal communi- } \\
\text { cation }\end{array}$ & The application of internal communication means \\
\hline \multirow[t]{2}{*}{ Rewarding } & Financial rewards & Relevant salary based on the job performed \\
\hline & $\begin{array}{l}\text { Non-financial } \\
\text { benefits }\end{array}$ & $\begin{array}{l}\text { Social and sporting events for employees. Extended } \\
\text { vacations. Gift vouchers }\end{array}$ \\
\hline \multirow{2}{*}{$\begin{array}{l}\text { Training and } \\
\text { development }\end{array}$} & Employee education & Training sessions and workshops \\
\hline & $\begin{array}{l}\text { Professional devel- } \\
\text { opment }\end{array}$ & Personal development plans \\
\hline Health and safety & Health services & $\begin{array}{l}\text { Assistance towards above-standard care. The provision } \\
\text { of vitamins, vaccinations against viral diseases, etc. }\end{array}$ \\
\hline
\end{tabular}


Table 2: (Continued)

\begin{tabular}{|c|c|c|}
\hline CSR themes & CSR activities & Examples of CSR activities \\
\hline \multicolumn{3}{|c|}{ Internal social policy tools } \\
\hline \multirow{3}{*}{$\begin{array}{l}\text { Balance between } \\
\text { one's personal } \\
\text { and professional } \\
\text { life }\end{array}$} & $\begin{array}{l}\text { Flexible forms of } \\
\text { work }\end{array}$ & $\begin{array}{l}\text { Flexible work hours. Work from home. Workplace } \\
\text { sharing }\end{array}$ \\
\hline & $\begin{array}{l}\text { Taking care of } \\
\text { children, seniors or } \\
\text { disabled persons }\end{array}$ & Psychological consultations. Allowance for day-care \\
\hline & $\begin{array}{l}\text { Employees on } \\
\text { parental vacation }\end{array}$ & $\begin{array}{l}\text { Possible contact during parental vacation. Support } \\
\text { when returning back to work }\end{array}$ \\
\hline Outplacement & $\begin{array}{l}\text { Support for dis- } \\
\text { missed employees }\end{array}$ & $\begin{array}{l}\text { Support in job searches. Offer to help with requalifica- } \\
\text { tion and training. Financial support }\end{array}$ \\
\hline \multirow[t]{2}{*}{$\begin{array}{l}\text { Equal opportuni- } \\
\text { ties }\end{array}$} & $\begin{array}{l}\text { Diversity in work- } \\
\text { places }\end{array}$ & $\begin{array}{l}\text { Giving jobs to people with an impaired position in the } \\
\text { labor market. Employment of the disabled, students, } \\
\text { seniors or persons who have been unemployed for a } \\
\text { long time }\end{array}$ \\
\hline & $\begin{array}{l}\text { Measures against } \\
\text { discrimination }\end{array}$ & $\begin{array}{l}\text { Fighting against discrimination in the workplace and } \\
\text { in the hiring of new employees }\end{array}$ \\
\hline \multicolumn{3}{|c|}{ External social policy tools } \\
\hline \multirow[t]{3}{*}{$\begin{array}{l}\text { Community sup- } \\
\text { port }\end{array}$} & Corporate donations & $\begin{array}{l}\text { Financial or material support. The provision of } \\
\text { services at a discount or for free. The rental of corpo- } \\
\text { rate facilities at a discount or for free }\end{array}$ \\
\hline & $\begin{array}{l}\text { Corporate } \\
\text { investment into the } \\
\text { local community }\end{array}$ & $\begin{array}{l}\text { Long-term relationships/connection with the } \\
\text { local community or partnerships with non-profit } \\
\text { organizations }\end{array}$ \\
\hline & $\begin{array}{l}\text { Fair Trade, } \\
\text { ethno-catering }\end{array}$ & $\begin{array}{l}\text { The use of fair trade products and ethno-catering at } \\
\text { corporate events, banquets or breakfasts }\end{array}$ \\
\hline \multirow[t]{2}{*}{$\begin{array}{l}\text { Cooperation with } \\
\text { schools }\end{array}$} & $\begin{array}{l}\text { Cooperation with } \\
\text { students }\end{array}$ & $\begin{array}{l}\text { Trainee-ship for students (or field days). Consultations } \\
\text { on diploma theses }\end{array}$ \\
\hline & $\begin{array}{l}\text { Support of } \\
\text { education }\end{array}$ & $\begin{array}{l}\text { The rental or provision of equipment to schools for } \\
\text { free. Lectures by experts }\end{array}$ \\
\hline \multirow[t]{2}{*}{$\begin{array}{l}\text { Involvement of } \\
\text { stakeholders }\end{array}$} & $\begin{array}{l}\text { The involvement of } \\
\text { employees }\end{array}$ & $\begin{array}{l}\text { Corporate voluntary actions. Benefit events with the } \\
\text { involvement of employees }\end{array}$ \\
\hline & $\begin{array}{l}\text { The involvement } \\
\text { of customers and } \\
\text { business partners }\end{array}$ & $\begin{array}{l}\text { The involvement of customers and business partners in } \\
\text { CSR activities }\end{array}$ \\
\hline
\end{tabular}

Source: Self-produced in accordance with [14].

CSR implementation in business practice is a voluntary decision taken by a company's management. The implementation of CSR tools into business practice is of course different for each individual business entity. CSR should be a component of strategy and strategic management. The introduction of CSR principles into a company's vision and mission is the highest level of CSR implementation in practice. This approach ensures the cohesion of individual tools within the 
Table 3: The environmental pillar of CSR.

\begin{tabular}{|c|c|c|}
\hline CSR themes & CSR activities & Examples of CSR activities \\
\hline \multirow[t]{5}{*}{$\begin{array}{l}\text { Environmental } \\
\text { policy }\end{array}$} & Management & $\begin{array}{l}\text { Environmental strategy implementation. The } \\
\text { application of IS } 14001 \text { and Eco Management } \\
\text { and Audit Scheme (EMAS) standards }\end{array}$ \\
\hline & Supply chain & $\begin{array}{l}\text { The implementation of environmental criteria } \\
\text { into supplier selection processes }\end{array}$ \\
\hline & $\begin{array}{l}\text { The involvement of stake- } \\
\text { holders }\end{array}$ & $\begin{array}{l}\text { Involvement and cooperation in environmental } \\
\text { activities }\end{array}$ \\
\hline & Communication & $\begin{array}{l}\text { Environmental training or distribution of infor- } \\
\text { mation on environmental activities }\end{array}$ \\
\hline & Climate change & $\begin{array}{l}\text { Following measures for reducing carbon foot- } \\
\text { prints }\end{array}$ \\
\hline \multirow[t]{4}{*}{ Energy and water } & Energy savings & $\begin{array}{l}\text { The implementation of measures and introduc- } \\
\text { tion of systems for saving energies (insulation, } \\
\text { energy-saving technologies etc.) }\end{array}$ \\
\hline & Renewable resources & The use of solar energy, biomass, etc. \\
\hline & Water savings & Measures and systems for water savings \\
\hline & Utility water & The use of utility water in production process \\
\hline \multirow[t]{2}{*}{ Waste and recycling } & Sorting and recycling & The sorting and recycling of paper, plastic, etc. \\
\hline & Waste reduction & $\begin{array}{l}\text { Printing on both sides of paper. Using returnable } \\
\text { barrels for drinking water, etc. }\end{array}$ \\
\hline Transportation & Transporting employees & $\begin{array}{l}\text { Support of environmental friendly commutes. } \\
\text { Reduction of business trips }\end{array}$ \\
\hline \multirow{3}{*}{$\begin{array}{l}\text { Products and pack- } \\
\text { ages }\end{array}$} & Transporting goods & Transport optimization through efficient logistics \\
\hline & Green products & $\begin{array}{l}\text { The manufacture of products and services with } \\
\text { an eco-label }\end{array}$ \\
\hline & Packaging materials & $\begin{array}{l}\text { Reducing packaging materials and a more fre- } \\
\text { quent use of eco-friendly packaging materials }\end{array}$ \\
\hline Purchasing & $\begin{array}{l}\text { Environmental-friendly } \\
\text { buying behaviors }\end{array}$ & $\begin{array}{l}\text { The use of recycled paper and green cleaning } \\
\text { agents }\end{array}$ \\
\hline
\end{tabular}

Source: Self-produced in accordance with [14].

company. CSR introduction into business practice should be systematic and strategic. It must be a long-term focused process. Not random, sudden or one-shot charity activities that could put the whole CSR concept in jeopardy - but rather, a systematic approach and long-term effects.

\section{THE RELATIONSHIP BETWEEN ERP SYSTEMS AND RESOURCE MANAGEMENT}

It is clear that most companies located mainly in market developed economies have entered the competition network that has moved from a local to a global business environment. Due to turbulently changing business and market environments, companies must be very efficient and adaptable if they 
want to survive in the market and be successful. One possible way for a company to be more efficient and adaptable is through the implementation of ERP systems into their business environment.

Grabski, Leech and Schmidt define and describe ERP systems as follows: 'ERP systems are typically the largest, most complex and most demanding information systems implemented by firms, representing a major departure from the individual and departmental information systems prevalent in the past'. ERP systems are one of the components that have a transformative force on the accounting profession, recording accounting transactions and evaluating accounting reports with an impact on auditing, risk management, the design of management control systems, organizational changes and strategies, firm benefits (internal, external), business processes, etc. [23].

Ahmad and Zulkifli stated that ERP systems could be a useful tool for companies. The main goal is to build a strong information system infrastructure and to enable management to make better decisions based on accurate and on-time information [24].

In the early 20th century, an approach that was focused on the relationship between the usage of natural resources and the costs and benefits resulting from business activities appeared for the first time. The link between natural resources and business needs was used to apply quantitative modeling to understand management options with a focus on the importance of integrating natural components and human needs into a solution of the optimal usage of natural resources in accordance with costs, revenues and profit [25].

Resource management gradually developed during the 20th century and since the beginning of the 21 st century, it has been crucial for many highly developed countries. All of this has resulted in a situation that sustainable management must consider these activities as intertwined systems [26]. ERP systems help to effectively record business processes and manage them. Based on the data obtained, information is prepared for management to help them make better decisions. This allows for the more efficient use of resources, including a subsequent decrease of costs and an increase of corporate profitability.

\section{INCREASING BUSINESS PERFORMANCE THROUGH SELECTED STRATEGIC MANAGEMENT MODELS}

Improving company performance is one of the basic preconditions for success in highly competitive environments. There are multiple methods that may help a company to improve its performance and efficiency. In the companies located in Central and Northeast Bohemia, the most frequently-used methods are the Balance Scorecard, Management by Objectives and Total Quality Management, as revealed answers to the survey (see Section 7). The above-mentioned companies usually have foreign parent companies in which the given methods are commonly used; therefore, they implement them to manage their daughter companies. The last two methods will be described in more detail hereinafter.

\subsection{Management by objectives}

The Management by Objectives and Self Control method was first described by Peter Ferdinand Drucker in his book released in 1955 under the title, The Practice of Management, and later in the second part of his book entitled Managing Managers. The key principal of this method is to achieve organizational goals by involving all persons interested in the relevant processes in the spirit of teamwork. The entire system is based on the presumption that people work better if they know what is exactly expected from them [27].

Peter Drucker thinks that ordinary employees should know exactly what they are doing and why, including what their company is supposed to achieve. In order to ensure this, top management must also know what it is doing and why. People at all levels of an organization must know what exactly 
they are supposed to do, what is expected from them and where they should move their company by doing so. On the other hand, they should know what can happen if their tasks are not fulfilled and what goals will not be met. Drucker is convinced that in order to run everything smoothly, employees from the level immediately below the main one involved should always be involved in making decisions regarding plans and in setting goals. Drucker further emphasizes the importance of the ability of each manager in an organization to correctly set goals. The goal setting process starts at the top management level, by setting the preliminary (overall) goals, including indicators to measure whether the goals have been met. These goals are modifiable and one of the greatest advantages of this method is the motivation felt by employees when they are given a chance to help in setting goals. Upon making lower level managers acquainted with preliminary goals and preconditions for planning, their supervisor may start with discussions regarding more detailed goals. The supervisor should ask his/her subordinates whether the overall goals are achievable, in what time frame and what resources will be required [27].

Management by objectives is a suitable tool that provides both employees and their managers with the opportunity to be actively involved in company operations/management and also to assume greater responsibility. This method has the following benefits and advantages: Management by objectives leads to an improvement of management, especially using the planning process. While compiling plans and schedules, managers must think about the objectivity, efficiency and achievability of the set goals. Another benefit is the clarification of the organizational structure and goals. During management by objectives implementation, organizations often realize weaknesses they would never notice. Competencies are delegated and responsibilities become more transparent. The third benefit is that Management by Objectives allows identification with goals and active participation in their achievement. This is why those involved/concerned have an internal feeling of responsibility. The fourth benefit is the development of efficient inspection. When goals are clearly set, it is much easier for managers to check on their subordinates. In addition, motivation is supported when employees set their goals by themselves - in this way, they motivate themselves to improve their individual performance. Another benefit is that during the delegation of tasks from upper to lower levels of an organization, weaknesses may be discovered. The last benefit of this method is the requirement for an objective assessment, i.e. goals must be measurable and clear. The level of achievement of individual goals may then be easily assessed, are transparent and are of course more objective [27].

\subsection{Total quality management}

With general progress, there are some social changes that come about that affect all aspects of human activities, including business. The shift in customer priorities, their needs and requirements is obvious and significant. Performance cannot be judged by quantity alone. The quantity of what is manufactured, the headcount and short-term profit may mean nothing to a company. Not only are final customers key but so are the relationship between the company and its employees and its communication with suppliers, dealers, etc.

Total quality management, as a strategic management model, is an integration philosophy based on a complex approach to management that works horizontally across an entire organization and is aimed at continuously improving quality and processes. It provides a framework for efficiently improving quality and work efficiency as the basic factors for increasing an organization's profitability and competitiveness. It identifies the challenges within a company and helps to set the goals that make the use of labor and materials most efficient to achieve the goals. The birth of the total quality management principle dates back to the first half of the 20th century. It was mainly developed in 
Japan where it helped the country to recover from a crisis and join global competition. The Japanese approach to total quality management can be divided into four basic concepts - Kaizen, Atarimae Hinshitsu, Kansei and Miryokuteki Hinshitsu. Kaizen is based on the continual improvement of processes through teamwork, personal discipline, high morale, quality meetings and proposals for innovation. Atarimae Hishitsu says that things should work exactly as we expect them to work. The Kansei philosophy says that the research into how customers actually use a company's products may the company to improve their quality. And last but not least - products should have some esthetic quality - the idea of Miryokuteki Hinshitsu [28].

These approaches are clearly understandable and logical, but thoroughly applying them in the western world is almost impossible. This, however, does not prevent the creation of a certain ideal that we all can look up to and follow - and this is the key message of total quality management.

Total quality management is a concept of quality management that is not - as one and only - based on standards or standardized instructions and recommendations. It is an open system that is based on clear principals, but its form must be always fully adapted to a specific organization. To apply total quality management efficiently, a specific model is needed. Of course, total quality management implementation starts with the top positions. Then, this principle of management must be gradually introduced to all employees and parties concerned. It must cover all activities and company elements. In sum, total quality management implementation is quite complex [28].

\section{RESULTS OF THE SURVEY}

Figure 2 presents the structure of the companies that were questioned and analyzed in accordance with EU legislation. Microenterprises are defined as companies with fewer than 10 employees. Their annual turnover and sum of assets shall not exceed 2 million EUR. Small enterprises are companies with fewer than 50 employees and their annual turnover and sum of assets shall not exceed 10 million EUR. Medium-sized enterprises are companies with fewer than 250 employees. Their annual turnover shall not exceed 50 million EUR and their sum of assets may not be higher than 43 million EUR. If a company does not meet any of the previously mentioned criteria, it is considered a large company [29].

Within the scope of the survey, companies were asked to provide information about their legal form of business. Fifty-two percent of them were limited companies (Ltd.), 30\% of them were public limited companies (Plc.), $12 \%$ of them were individual entrepreneurs, $2 \%$ of them were cooperatives and the rest had other legal forms of business in accordance with the Czech legislation.

One part of the survey was focused on the problems associated with the use of ERP systems that are intended for recording accounting transactions, managerial accounting and for the needs of strategic management in general. Figure 3 shows the structure of ERP systems used in the analyzed companies situated in the Czech Republic. The majority of the companies were owned by foreign

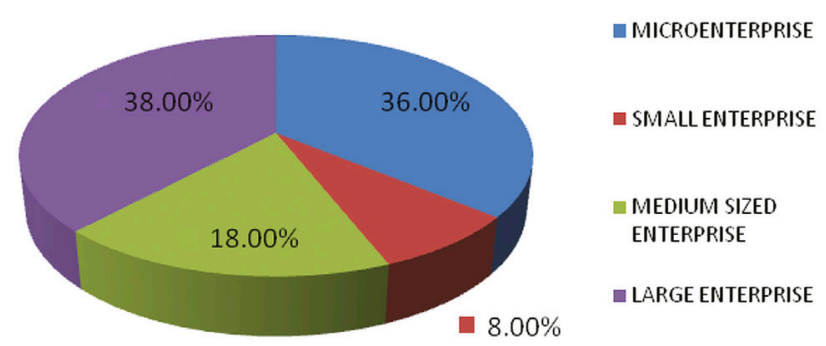

Figure 2: The size of a company in accordance with EU legislation. Source: self-produced. 


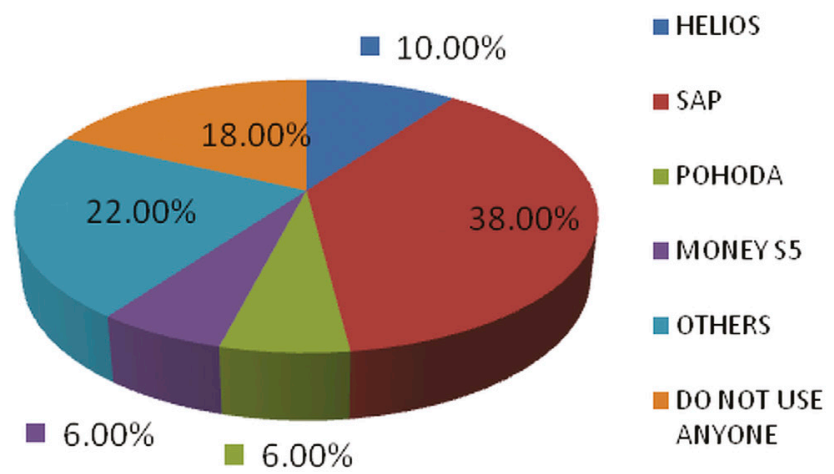

Figure 3: The structure of used enterprise resource planning systems in the analyzed companies. Source: self-produced.

entities and the system was chosen because an ERP system is currently being used by their parent company or because the system is used by their suppliers or customers. A lot of analyzed companies were involved with automotive manufacturing. The most frequently used ERP system is SAP, which was present in $38 \%$ of the companies who responded.

Based on the ERP System used, the respondents answered their level of satisfaction with the system they use in terms of its functionality. The results revealed that $11.11 \%$ of the respondents were satisfied with their ERP system, $66.67 \%$ of the respondents were mostly satisfied with it and did not have any crucial critical comments on the functionality of the system. Only $3.7 \%$ of the questioned respondents were dissatisfied with the ERP system that was used by the company in which they worked. The rest were mostly dissatisfied.

With regard to the concept of sustainable development, the companies were asked if they use financial analysis to evaluate their performance and financial health. Eighty-four percent of them answered yes while the rest do not. This result corresponds with the structure of chosen companies that were analyzed. It is mainly microenterprises that do not prepare data for making management decisions. If a company prepares an annual financial analysis, there is a good possibility that the company's resources such as finance, human resources, energy use and production resources will be used better. $27.66 \%$ of the respondents use financial analysis for making planning decisions. Within the companies analyzed, another major goal (with a share of 21.28\%) of the data obtained from a financial analysis is based on setting strategic goals. Feedback for controlling it was stated by $20.21 \%$ of the companies. The most surprising outcome of the survey was the fact that some of the companies analyzed do not use the data obtained from a financial analysis for any purpose at all. This may particularly be caused by the fact that the companies might have set management criteria that is different from the standard indicators of a financial analysis, or this reality may be caused by financial managers' reluctance to work with outputs from a financial analysis.

Part of the research dealing with corporate performance is the use of strategic management models. From the survey, it was determined that $76.00 \%$ of the analyzed companies do not use any model of strategic management, $12.00 \%$ of them use balanced scorecard, $6 \%$ of them total quality management and the rest use management by objectives.

The next question was based on an analysis of the implementation of the strategic management model. $63.64 \%$ of the companies that use a strategic management model implemented that model individually. $27.27 \%$ of the analyzed companies used the services of an external consulting company and the rest of the companies were not able to answer the question. Implementing some strategic 


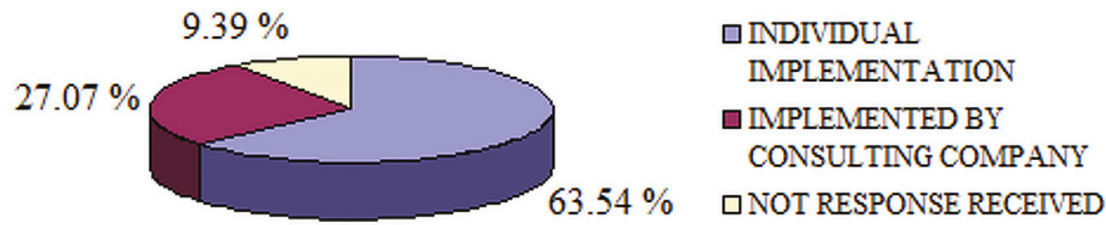

Figure 4: Implementing a strategic management model. Source: self-produced.

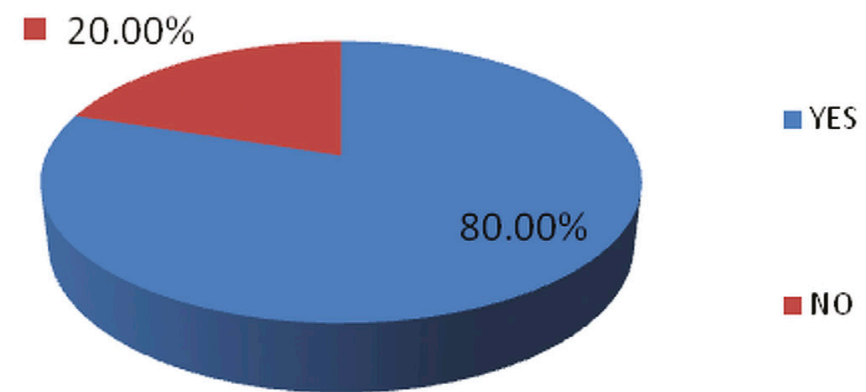

Figure 5: The integration of corporate social responsibility in the companies. Source: self-produced

management model helps a company to improve and streamline its business operations with a focus on better usage of all resources used in production, as shown in Fig. 4. How the strategic management model is implemented influences how much the implementation costs and, the speed and efficiency of the system's implementation and the relevance of presented data.

As a part of resource management, we must also consider CSR. The companies were asked if they incorporate CSR in their corporate environment. $80.00 \%$ of the analyzed companies have implemented it and only $20.00 \%$ of the companies have not yet addressed CSR, as shown in Fig. 5. The result was relatively surprising and it can be explained by the fact that a lot of the questioned companies were owned by foreign entities.

Companies in the automotive industry rank tops among the types of companies that include CSR in their corporate environment and simultaneously report their individual activities. It is possible to state that the most frequently used method of reporting CSR is the Global Reporting Initiative method.

\section{CONCLUSION}

A socially responsible corporation is characterized by its responsible behavior and activities towards its surroundings. This can be divided into three basic areas - economic, which is mainly oriented on profit, social, which is aimed at people and environmental, which is focused on planet Earth. Therefore, we talk about 3P (profit, people, planet). The application of 3P means a company is focused not only on economic growth, but also on the environmental and social aspects of its activities with regard to the Triple-Bottom-Line. The main idea behind this concept is that the company's performance may be - in addition to the traditional economic indicators - also measured by its social and environmental attitudes [30].

ERP systems allow businesses to accurately and efficiently monitor the costs of the company. These costs can be managed by the company. Cost Management enables more efficient use of inputs and leads to a reduction of corporate costs, which leads to better financial performance. This situa- 
tion has a positive impact on profit. On the basis of the higher profit enterprises levy higher taxes to the state budget. After that the taxes are being used for redistribution in the economy and may thus lead to elimination the negative impact of business activities on the environment. The aim of the survey was to determine which Enterprise Resource Planning systems companies use to track costs, what methods are used for improving the financial performance of companies and if the companies follow the rules connected with the CSR.

The Management by Objectives methodology provides the opportunity to gain a huge labor potential. It is a suitable tool used by a company to achieve its strategic goals and to improve the performance of its individual employees by involving all of them in the organization's management. It also motivates employees on all levels (including top managers) to perform even better. It allows for a more efficient inspection and coordination of activities as well as for an earlier revision of procedures or even goals. The employees - due to their higher level of motivation, self-fulfillment and active involvement in the organization's activities - achieve greater levels of efficiency and selfsatisfaction. It is very important not to underestimate this method and take some time to apply it thoroughly in order to avoid the problems mentioned herein. Because of its complexity, it is bettersuited for medium-sized and large organizations where it may occur quite often that the employees do not precisely know the organization's goals (and even their own goals). Managers, who must correctly set the goals, are quite important for the successful implementation of the Management by Objectives method.

Total quality management brings many benefits that may be crucial for obtaining a competitive advantage while maintaining quality services and products. By implementing the total quality management model, quantities of scrap are significantly reduced and so are the costs, which lead to an overall increase in efficiency.

The results of our survey confirmed that companies mainly use financial analysis for measuring their performance and for company management purposes. This result corresponds with the size and legal form of the company. Because of the criticism of the traditional methods used to measure business performance, some innovations have been implemented. Recently, due to turbulent changes in the economic environment, companies are more increasingly using complex models for management and measuring their performance. These models include balanced scorecard, total quality management and management by objectives.

\section{ACKNOWLEDGEMENTS}

This article was written as one of the outputs of the research project entitled 'The analysis of data applicability from a company's SAP information system when forming a financial plan', which was conducted at the Faculty of Economics at the Technical University of Liberec in 2013 with the financial support from the Technical University in the competition that supported specific projects of academic research (a student grant competition).

\section{REFERENCES}

[1] Lompo, M.K., Ballet, J. \& Dubios, J.-L., Sustainable human development and the capability approach: Integrating Environment, Responsibility and Collective Agency. Journal of Human Development and Capabilities: A Multi-Disciplinary Journal for People-Centered Development, 14(1), pp. 77-94, 2013. doi: http://dx.doi.org/10.1080/19452829.2012.747491

[2] Bowen, H.R., Social Responsibilities of the Businessman. Iowa City: University of Iowa Press, pp. 10-33, 2013.

[3] Jáčová, H., Brabec, Z. \& Horák, J., New management systems and their application through ERP Systems in the Czech Republic. Proceedings of the 11 th International Conference Liberec Economic Forum. Liberec: Technical University of Liberec, pp. 231-239, 2013. 
[4] Liberatore, A. The integration of sustainable development objectives into EU policy-making. The Politics of Sustainable Development Theory, Policy and Practice Within the European Union. New York: Routledge, pp. 107-126, 2002.

[5] Waas, T., Verbruggen, A. \& Wright, T., University research for sustainable development: definition and characteristics explored. Journal of Cleaner Production, 18(1), pp. 107-126, 2010. doi: http://dx.doi.org/10.1016/j.jclepro.2009.09.017

[6] Ševčík, O., Naše společná budoucnost: světová komise pro životní prostředí a rozvoj. Academia: Praha, pp. 47, 1991.

[7] Daly, H. \& Cobb, J., For the Common Good, Boston: Beacon Press, 1989.

[8] Vavroušek, J., Perspektivy lidských hodnot slučitelných s trvale udržitelným způsobem života, www.sustainable.cz/josefvavrousek.htm

[9] Rynda, I., Trvale udržitelný rozvoj a vzdělávání, Hledání odpovědí na výzvy současného světa, ed. J. Dlouhá, Společnost pro trvale udržitelný život: Prague, pp. 10-16, 2000.

[10] Lehtonen, M., The environmental-social interface of sustainable development: capabilities, social capital, insitutions. Ecological Economics, 49(2), pp. 199-214, 2004. doi: http://dx.doi. org/10.1016/j.ecolecon.2004.03.019

[11] Damtoft, J.S., Lukasik, J., Herfort, D., \& Sorrentino, D., Sustainable development and climate change initiatives. Cement and Concrete Research, 38(2), pp. 115-127, 2008.

[12] Černíková, M. \& Malíková, O., Capital structure of an enterprise - open questions regarding its displaying under the Czech Legislative conditions. Proceedings of the 11th International Conference Liberec Economic Forum 2013, ed. A. Kocourek, Technical University of Liberec: Liberec, pp. 104-113, 2013.

[13] White, L. \& Gregory, J.L., Operational research and sustainable development: tackling the social dimension. European Journal of Operational Research, 193(3), pp. 683-692, 2009. doi: http://dx.doi.org/10.1016/j.ejor.2007.06.057

[14] Prskavcová, M., Maršíková, K., Řehořová, P., \& Zbránková, M., Společenská odpovědnost firem, lidský kapitál, rovné příležitosti a environmentální management s využitím zahraničních zkušeností. Brno: Tribun EU, pp. 10-11, 2008.

[15] Bowen, H.R., Social Responsibility of the Businessman. New York: Harper \& Row, 1953.

[16] Friedman, M., Capitalism and Freedom. Chicago: University of Chicago Press, 1962.

[17] Aras, G. \& Crowther, D.J., The social obligation of corporations. Journal of Knowledge Globalization, 1(1), pp. 43-59, 2008.

[18] Levitt, T., The dangers of social responsibility. Harvard Business Review, 36(5), pp. 41-50, 1958.

[19] Mohr, L.A. \& Webb, D.J., The effects of corporate social responsibility and price on consumer response. The Journal of Consumer Affairs, 39(1), pp. 121-147, 2005. doi: http://dx.doi. org/10.1111/j.1745-6606.2005.00006.x

[20] European Commission. Corporate Social Responsibility (CSR) [online] [cited 4 December 2014]. Available from: http://ec.europa.eu/enterprise/policies/sustainable-business/corporatesocial-responsibility/index_en.htm

[21] Dahlsrud, A., How corporate social responsibility is defined: an analysis of 37 definitions. Corporate Social Responsibility and Environmental Management, 15, pp. 1-13, 2008. doi: http://dx.doi.org/10.1002/csr.132

[22] Carroll, A.B., Corporate social responsibility evolution of a definitional construct. Business Society, 38(3), pp. 268-295, 1999. doi: http://dx.doi.org/10.1177/000765039903800303

[23] Grabski, S.V., Leech, S.A. \& Schmidt, P.J., A review of ERP research: a future agenda for accounting information systems. Journal of Information Systems, 25(1), pp. 37-78, 2011. doi: http://dx.doi.org/10.2308/jis.2011.25.1.37 
[24] Ahmad, S.S. \& Zulkifli, M.U., The relationship between ERP system and supply chain management performance in Malaysian manufacturing companies. Journal of Enterprise Information Management, 25(6), pp. 576-604, 2012. doi: http://dx.doi.org/10.1108/17410391211272847

[25] Holmes, J.K. \& Wolman, M.G., Early development of system analysis in natural resources management from man and nature to the Miami Conservancy District. Environmental Management, 27(2), pp. 177-193, 2001. doi: http://dx.doi.org/10.1007/s002670010142

[26] Knüppe, K. \& Pahl-Wostl, C., A framework for the analysis of governance structures applying to groundwater resources and the requirements for the sustainable management of associated ecosystem services. Water Resources Management, 25(13), pp. 3387-3411, 2011. doi: http:// dx.doi.org/10.1007/s11269-011-9861-7

[27] Drucker, P.F., The Practice of Management. New Delhi: Private Limited, 2004.

[28] Morfaw, J.N., Total Quality Management. Lanham: University Press of America, 2009.

[29] Structural funds. Ministry of Regional Development of the Czech Republic, http://www. strukturalni-fondy.cz/cs/Fondy-EU/Programy-2007-2013/Operacni-programy-Praha/ OP-Praha-Adaptabilita/Novinky/Pomucka-pro-urceni-velikosti-podniku

[30] Lindgree, A. \& Swaen V., Corporate social responsibility. International Journal of Management Reviews, 12(1), pp. 1-7, 2010. 